\title{
PREPARATION AND CHARACTERIZATION OF ACTIVATED CARBON FROM BEAN HUSK
}

\author{
E. T. Evwierhoma ${ }^{1,}{ }^{*}$, 0. D. Madubiko ${ }^{2}$ and A. Jaiyeola ${ }^{3}$ \\ 1,2,3, DEPARTMENT OF CHEMICAL ENGINEERING, UNIVERSITY OF LAGOS, AKOKA, LAGOS STATE, NIGERIA \\ E-mail addresses:1eevwierhoma@unila.edu.ng,2iroko4live@yahoo.com,3lekejaiyeola@yahoo.com
}

\begin{abstract}
The optimal process conditions for the preparation of activated carbon from bean husk were investigated in this study. Four chemical activating agents; potassium hydroxide ( $\mathrm{KOH}$ ), sulphuric acid $\left(\mathrm{H}_{2} \mathrm{SO}_{4}\right)$, zinc chloride $\left(\mathrm{ZnCl}_{2}\right)$, and ortho-phosphoric acid $\left(\mathrm{H}_{3} \mathrm{PO}_{4}\right)$ were used to activate the carbon. The influence of these agents on the surface area and porosity of activated carbon was determined. The Iodine numbers of $894.65,1027.69,1218.24$ and $1256.31 \mathrm{mg} / \mathrm{g}$ were found for the $\mathrm{KOH}, \mathrm{H}_{2} \mathrm{SO}_{4}, \mathrm{ZnCl}_{2}$ and $\mathrm{H}_{3} \mathrm{PO}_{4}$ activated carbons respectively. This indicates that the one prepared using ortho-phosphoric acid $\left(\mathrm{H}_{3} \mathrm{PO}_{4}\right)$ produced the best activated carbon. The influence of activation temperature was studied between $500{ }^{\circ} \mathrm{C}$ and $900^{\circ} \mathrm{C}$. The effect of activation temperature shows an optimum temperature of $700^{\circ} \mathrm{C}$ at the time of 30mins. Further studies revealed that the best impregnation ratio of carbon to ortho-phosphoric acid was 10:5as it gave a maximum iodine number of 1288.926.The results of the characterization show that the values of apparent density, ash content, moisture content and $\mathrm{pH}$ of the activated carbon fall within the range recommended by ASTM. This activated carbon is suitable for the treatment of effluent water and gases.
\end{abstract}

Keywords: Bean husk; Activated carbon; optimum temperature; impregnation ratio; Activating agent.

\section{INTRODUCTION}

Activated carbon (AC) is one of the most commonly used adsorbents in many different liquids and gas phase applications in the industry for its adsorptive properties. AC is used in gas purification, gold purification, metal extraction, water purification, medicine, sewage treatment, air filters in gas masks and respirators, filters in compressed air and many other applications.

It can be produced from any carbonaceous solid precursor which may be either natural or synthetic substances by one or two general methods of manufacture, each of which includes thermal decomposition of the parent materials. These materials include the fibrous forms found in vegetation and agricultural wastes. The development of methods to reuse waste materials is greatly desired and the production of AC from wastes offers a promising future. A wide variety of agricultural by-products and wastes have been investigated as precursors for the production of AC. These precursors include coconut shell and wood [1], Olive stones [2, 3], sugarcane, corncorb, pecan shells, [4], palm seed, [5] apple pulp, [6] rubber seeds [7] Commercial activated carbons are commonly produced from naturally occurring carbonaceous materials such as coal, wood and peat. [8]. Due to the growing need for activated carbons in our society and the high cost of raw materials and production, many researchers have attempted various wastes such as tires, [9], agricultural byproducts [4], as raw materials and proposed new production methods for activated carbons with potential applications in pollution control. Furthermore, more interest has been devoted to utilize some wastes of carbonaceous materials such as paper [10], molasses [11] and sewage sludge [12].

Considering the large amounts of beans husk being dumped in our environment today, there is need to investigate ways of recycling this waste. This work focused on the optimum conditions required for the preparation of activated carbon from bean husk (Phaseolus vulgaris) using four activating agents and characterization of the activated carbon produced.

\section{MATERIALS}

The bean husks and the reagents were locally sourced in Lagos State, Nigeria. The chemicals used for the impregnation were laboratory grade potassium 
hydroxide $(\mathrm{KOH})$, sulphuric acid $\left(\mathrm{H}_{2} \mathrm{SO}_{4}\right)$, zinc chloride $\left(\mathrm{ZnCl}_{2}\right)$, sodium thiosulphate solution $\left(\mathrm{Na}_{2} \mathrm{~S}_{2} \mathrm{O}_{3} \cdot 5 \mathrm{H}_{2} \mathrm{O}\right)$, starch, iodine solutions and orthophosphoric acid $\left(\mathrm{H}_{3} \mathrm{PO}_{4}\right)$.

\section{EXPERIMENTAL PROCEDURE}

The procedures involved in the production of the activated carbon include:

a.) Pre-treatment of the bean husk sample

b.) Grinding and sieving of bean husk sample

c.) Carbonization of the bean husk sample

d.) Activation of bean husk using potassium hydroxide $(\mathrm{KOH})$, sulphuric acid $\left(\mathrm{H}_{2} \mathrm{SO}_{4}\right)$, zinc chloride $\left(\mathrm{ZnCl}_{2}\right)$, and Orthophosphoric acid $\left(\mathrm{H}_{3} \mathrm{PO}_{4}\right)$

e.) Acid washing

f.) Iodine number identification

g.) Analysis of factors affecting the activated carbon produced

\subsection{Pre-treatment}

The bean husk was obtained by removing the bean seeds. It was washed in clean water and sundried. It was oven dried at $105^{\circ} \mathrm{C}$ for 20 minutes. Then it was ground and sieved and ready for carbonization.

\subsection{Carbonization}

Samples of the precursor after pre-treatment were heated in the muffle furnace at a temperature of $500^{\circ} \mathrm{C}$ for1hour and allowed to cool. The carbonized samples were crushed, ground and sieved with a mechanical sieve; SETHI standard test sieve to obtain particle sizes need for further studies. The pulverized samples collected at the $300 \mathrm{~mm}$ mesh were used for activation.

\subsection{Chemical Activation}

Some quantity of the activating agents namely potassium hydroxide $(\mathrm{KOH})$, sulphuric acid $\left(\mathrm{H}_{2} \mathrm{SO}_{4}\right)$, zinc chloride $\left(\mathrm{ZnCl}_{2}\right)$, and otho-phosphoric acid $\left(\mathrm{H}_{3} \mathrm{PO}_{4}\right)$, were measured, made to form slurry by mixing with measured quantity of carbon in the weight ratio of $1: 5$ in a crucible.

$20.4 \mathrm{ml}$ each of $1 \mathrm{~N} \mathrm{H}_{3} \mathrm{PO}_{4}$ and $1 \mathrm{~N} \mathrm{H}_{2} \mathrm{SO}_{4}$ were measured into a crucible containing $5 \mathrm{~g}$ carbon carefully measured to form slurry and stirred properly for 30 minutes. This $20.4 \mathrm{ml}$ is equivalent to $1 \mathrm{~g}$ of the activating chemicals.

Also, $1 \mathrm{~g}$ each of $\mathrm{ZnCl}_{2}$ and $\mathrm{KOH}$ were weighed into a beaker, $10 \mathrm{ml}$ of de-ionized water added to form solution. The solution was poured into a crucible containing $5 \mathrm{~g}$ of carbon carefully measured to form slurry and stirred for 30mins. This gave 1:5 impregnation ratio of activating agent to carbon.

The four samples prepared with the four activating agents were oven dried for $24 \mathrm{hrs}$ at $105^{\circ} \mathrm{C}$ in NYC101 oven FCD3000 serial and allowed to cool. After cooling, the samples were activated in the furnace for $30 \mathrm{mins}$ at $700^{\circ} \mathrm{C}$.

This was followed by soaking the activated carbon in $0.1 \mathrm{~N} \mathrm{HCl}$, and stirred for 30 mins and allowed to stand for $24 \mathrm{hrs}$ and washing with distilled water until the $\mathrm{pH}$ is in the range of 6-7using a pH 209 Hannah meter.

After acid washing, the samples were sun dried and further oven dried for $24 \mathrm{hrs}$ at $105^{\circ} \mathrm{C}$ and further weighed to determine the percentage yield of the products. Finally the samples were stored in tight closed bottles ready for analysis and iodine adsorption.

\subsection{Yield Calculation}

The yield of activated carbon which is defined as the ratio offinal weight of the obtained product after washing and drying to the weight of dried precursor initially used was calculated using the following equation [13]:

$$
\text { Yield }(\%)=\frac{W_{f}}{W_{o}} \times 100
$$

Where $W_{o}$ and $W_{f}$ are the initial and final weights of activated carbon product (g) the weight of dried carbon before activation (g), respectively.

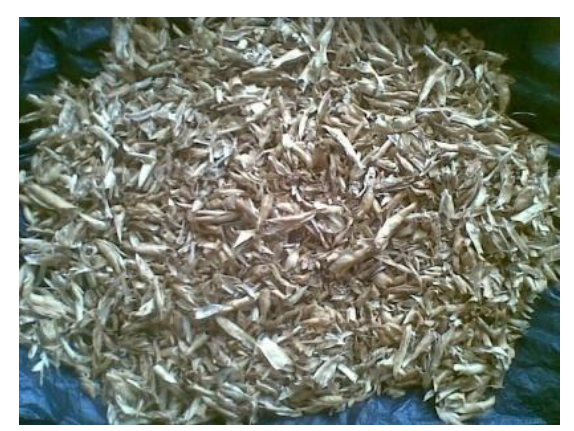

Fig. 1 Pre-treated bean husk at $105^{\circ} \mathrm{C}$

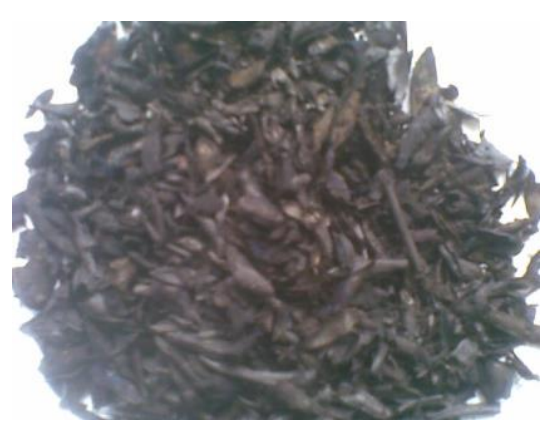

Fig.2 Carbonized bean husk at $500^{\circ} \mathrm{C}$

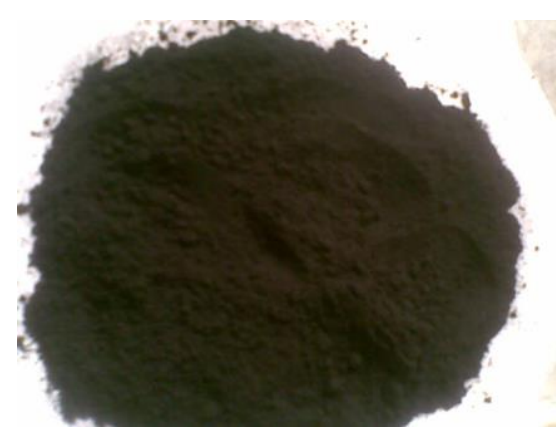

Fig.3 Activated bean husk carbon at $700^{\circ} \mathrm{C}$ 


\subsection{Effect of activating agent on Iodine number}

Iodine number which is a measure of the micro pore content of activated carbon $\left(0-20 \mathrm{~A}^{\circ}\right)$ was determined by standard method [14]. $10 \mathrm{ml}$ of $0.1 \mathrm{~N}$ iodine solution in a conical flask was titrated with $0.1 \mathrm{~N}$ sodium thiosulfate solution in the presence of 2 drops of $1 \mathrm{wt} \%$ starch solution as indicator, until the solution became colourless. Then $0.05 \mathrm{~g}$ of activated carbon was added to conical flask containing $15 \mathrm{ml}$ of $0.1 \mathrm{~N}$ iodine solution and the mixture was shaken for 4 min then filtered. $10 \mathrm{ml}$ of filtrate was titrated with standard sodium thiosulfate solution using 2 drops of starch solution as indicator. The iodine number was then calculated by the using the following equation [15]:

$$
\text { iodine number }=\left(\frac{V_{b}-V_{s}}{M}\right) N(126.9)\left(\frac{15}{10}\right)
$$

In (2), $V_{b}$ and $V_{s}(\mathrm{ml})$ are volumes of sodium thiosulfate solution required for blank and sample titrations, respectively, $\mathrm{N}$ (mol/L) is the normality of sodium thiosulfate solution, 126.9 is the atomic weight of iodine, and M (g) is the mass of activated carbon used. The four oxidizing agents above gave different iodine numbers see (Table 1). Orthophosphoric acid $\left(\mathrm{H}_{3} \mathrm{PO}_{4}\right)$ was the best activating agent followed by zinc chloride based on the iodine numbers. The following further studies were carried out on the Orthophosphoric acid $\left(\mathrm{H}_{3} \mathrm{PO}_{4}\right)$ impregnated $\mathrm{AC}$ to ascertain more optimum conditions.

\subsubsection{Effect of activation temperature on iodine number.}

Using $\mathrm{H}_{3} \mathrm{PO}_{4}$ as the best activation chemical based on the iodine number, the optimum activation temperature was determined by varying the temperature of activation between 500, 600, 700, 800, $900^{\circ} \mathrm{C}$ using the same impregnation ratio of $1: 5$ for $30 \mathrm{mins}$ each in a furnace. With this the iodine number and the yield percent were determined. From the table, the iodine value increases with temperature and became highest at $700^{\circ} \mathrm{C}$ before decreasing while the $\%$ yield decreases with increase in temperature.

\subsubsection{Effect of activation time on iodine number}

The effect of activation time on iodine number and yield of activated carbon produced was determined by varying the activation time at the optimum activation temperature of $700^{\circ} \mathrm{C}$ and $1: 5$ impregnation ratio. The time variation were; $20 \mathrm{mins}$, $30 \mathrm{mins}$, $40 \mathrm{mins}$, $50 \mathrm{mins}$ and 60 mins. $5 \mathrm{~g}$ of the carbon was mixed with $1 \mathrm{~g}$ (20.4ml) of $0.1 \mathrm{~N} \mathrm{H}_{3} \mathrm{PO}_{4}$ made into slurry and activate at $700^{\circ} \mathrm{C}$ for $20,30,40,50$, and $60 \mathrm{mins}$ in the furnace.

\subsubsection{Effect of impregnation ratio on iodine number}

The effect of impregnation ratio was determined by varying the impregnation ratio at the optimum temperature and time of $700^{\circ} \mathrm{C}$ for $30 \mathrm{mins}$. $5 \mathrm{~g}$ of carbon was mixed with $1 \mathrm{~g}, 2 \mathrm{~g}, 3 \mathrm{~g}, 4 \mathrm{~g}$ and $5 \mathrm{~g}$ of $0.1 \mathrm{~N}$ $\mathrm{H}_{3} \mathrm{PO}_{4}$. This corresponds to 1:5, 2:5, 3:5, 4:5, 5:5, 10:5 and 15:5 impregnation ratios. At these ratios the samples were activated at $700^{\circ} \mathrm{C}$ for $30 \mathrm{mins}$. The prepared activated carbon was further characterized by selected physical properties. These include moisture content, bulk density and the chemical properties used were ash content and $\mathrm{pH}$.

\subsection{Moisture content}

$2 \mathrm{~g}$ of activated carbon was placed in a Petri plate and heated in an oven at $100 \pm 5^{\circ} \mathrm{C}$ for 1 hour. It was cooled in a desiccator and then weighed. The process of heating, cooling and weighing was repeated at $30 \mathrm{~min}$. time intervals until the difference between the consecutive weighing was $\pm 0.01 \mathrm{~g}$.

The moisture content was calculated by the following equation:

$$
\text { Moisture (\%) }=\frac{W_{m 3}-W_{m 2}}{W_{m 1}} \times 100
$$

Where $\mathrm{Wm}_{3}(\mathrm{~g})$ is the weight of crucible containing original sample, $\mathrm{Wm}_{2}$ (g) is the weight of crucible containing dried sample, and $\mathrm{Wm}_{1}(\mathrm{~g})$ is the weight of original sample used.

\subsection{Bulk density}

Bulk or apparent density was determined as follows: A $100 \mathrm{ml}$ graduated cylinder was weighed accurately. Sufficient amount of carbon was filled with constant tapping and up to $50 \mathrm{ml}$ mark. After filling the graduated cylinder with the carbon, the bulk density was then calculated as follows:

$$
\text { Bulk density }=\frac{W_{C}}{V_{C}}
$$

Where $\mathrm{W}_{\mathrm{C}}(\mathrm{g})$ is the weight of dried activated carbon and $\mathrm{V}_{\mathrm{C}}(\mathrm{ml})$ is cylinder volume packed with dried activated carbon.

\subsection{Ash content}

The ash content was determined by standard methods [16]. $2 \mathrm{~g}$ of activated carbon was dried at $80^{\circ} \mathrm{C}$ for $24 \mathrm{~h}$ and placed into weighed ceramic crucibles. The samples were heated in an electrical furnace at $650^{\circ} \mathrm{C}$ for $3 \mathrm{~h}$. Then the crucibles were cooled to ambient temperature and weighed. The percent of ash was calculated as follows:

$$
\operatorname{Ash}(\%)=\frac{W_{S 3}-W_{S 2}}{W_{S 1}} \times 100
$$


Where $\mathrm{WS}_{3}$ (g) is the weight of crucible containing ash, $\mathrm{WS}_{2}$ (g) is the weight of crucible containing heated sample and $\mathrm{WS}_{1}(\mathrm{~g})$ is the weight of original activated carbon used.

\section{$3.9 \mathrm{pH}$}

$1 \mathrm{~g}$ of activated carbon in $50 \mathrm{ml}$ of distilled water was agitated for 30mins. The filtrate was tested for $\mathrm{pH}$ using $\mathrm{pH}$ meter. The result obtained from this analysis conforms to the values stated in American Society for Testing and Materials (ASTM) standard specified values for activated carbons. The result is shown in Table 5.

\section{RESULTS}

The results of AC preparation and characterization are presented in Table 1 - 5. Table 1 shows the iodine number values of the four activating agents while Table 2 - 4 shown the activation temperature, time and impregnation ratio respectively. The values of moisture and ash contents as well as $\mathrm{pH}$ are shown in Table 5. The iodine number was maximum at 30 mins before it started decreasing while the \% yield decreases with increase in activation time indicating a conversion to ash on prolonged activation time.

\begin{tabular}{lll}
\multicolumn{3}{c}{ Table 1 Effect of activating agent on iodine number } \\
\hline s/n & Activation chemical & Iodine number $(\mathrm{mg} / \mathrm{g})$ \\
\hline 1 & $\mathrm{H}_{3} \mathrm{PO}_{4}$ & $1,256.31$ \\
2 & $\mathrm{ZnCl}_{2}$ & $1,218.24$ \\
3 & $\mathrm{H}_{2} \mathrm{SO}_{4}$ & $1,027,89$ \\
4 & $\mathrm{KOH}$ & 894.648 \\
5 & Unactivated carbon & No visible change \\
\hline
\end{tabular}

Table 2: Effect of activation temperature on the iodine

\begin{tabular}{llll}
\multicolumn{3}{c}{ number and yield. } \\
\hline $\mathrm{s} / \mathrm{n}$ & $\begin{array}{l}\text { Temp. } \\
\left({ }^{\circ} \mathrm{C}\right)\end{array}$ & Iodine number $(\mathrm{mg} / \mathrm{g})$ & $\begin{array}{l}\text { Yield } \\
\%\end{array}$ \\
\hline 1 & 500 & 609.12 & 75.60 \\
2 & 600 & 875.61 & 61.40 \\
3 & 700 & 1256.31 & 57.40 \\
4 & 800 & 951.75 & 53.20 \\
5 & 900 & 837.54 & 34.20 \\
\hline
\end{tabular}

Table.3: Effect of activation time on iodine number and

\begin{tabular}{llll}
\multicolumn{3}{c}{ yield } \\
\hline S/N & Time (mins) & Iodine number $(\mathrm{mg} / \mathrm{g})$ & Yield \% \\
\hline 1 & 20 & 951.75 & 62.00 \\
2 & 30 & 1256.31 & 57.40 \\
3 & 40 & 1020.26 & 45.14 \\
4 & 50 & 1008.86 & 33.80 \\
5 & 60 & 993.62 & 28.00 \\
\hline
\end{tabular}

Table. 4: Effect of impregnation ratio on iodine number and yield

\begin{tabular}{llll}
\hline s/n & Ratio & Iodine number $\mathrm{mg} / \mathrm{g}$ & Yield \% \\
\hline 1 & $1: 5$ & 1256.310 & 57.40 \\
2 & $2: 5$ & 1260.002 & 57.40 \\
3 & $3: 5$ & 1275.345 & 57.40 \\
4 & $4: 5$ & 1282.959 & 57.39 \\
5 & $5: 5$ & 1286.766 & 5739 \\
6 & $10: 5$ & 1288.926 & 57.385 \\
7 & $15: 5$ & 1288.928 & 57.384 \\
\hline
\end{tabular}

Table 5: Characterization parameters of the activated carbon.

\begin{tabular}{ll}
\hline Moisture content \% & 8.50 \\
\hline Ash content \% & 3.50 \\
Bulk density g/ml & 0.41 \\
$\mathrm{pH}$ & 6.70 \\
\hline
\end{tabular}

\section{DISCUSSION}

Iodine number measurement is a commonly used method to characterize activated carbon performance. This number compares the adsorptive characteristics of the activated carbons prepared using the four activating agents. Table 1 shows the various values of iodine number obtained using the different activating agents. It can be seen that the phosphorous impregnated carbon gave the highest value of iodine number (1256.31mg of iodine/g of carbon) while that with $\mathrm{KOH}$ gave the lowest value (894.65mg iodine/g of carbon). $\mathrm{ZnCl}_{2}$ and $\mathrm{H}_{2} \mathrm{SO}_{4}$ impregnated carbons also gave high iodine values but they pose high pollution problems. Generally, these high values suggest that there are large micropore and mesopore structures which favour chemisorption.

The phosphorous impregnated carbon obtained at $500^{\circ} \mathrm{C}$ and 1 hour (carbonization condition)was further subjected to variations of temperature and time of activation to determine the optimum temperature and activation time. Tables 2 and 3 show these effects. The iodine value increases with temperature and became highest at $700^{\circ} \mathrm{C}$ before decreasing while the \% yield decreases with increase in temperature.

Thus $700^{\circ} \mathrm{C}$ was the optimum activating temperature and the decrease in \% yield indicates that the higher the temperature the more the carbon turns to ash on prolonged activation time resulting to low yield. The activation temperature of $700^{\circ} \mathrm{C}$ gave the highest iodine number with a reasonable yield of $57.4 \%$ of activated carbon. However, the yield was higher below this temperature but the iodine number was low in table 3, it can be seen that the yield decreases sharply as activation time increases as the carbon is converted to ash. The iodine number gets to the maximum at $30 \mathrm{mins}$ 
and decreases thereafter. Table 4 shows the effect of impregnation ratio. The iodine number increases steadily with increasing ratio and reaches a maximum at 10:5 and attained equilibrium at this ratio while the $\%$ yield remained almost constant with increase in impregnation ratio. The other parameters determined at this optimum condition were moisture content, ash content, bulk density and the $\mathrm{pH}$. These are shown in Table 5. The activated carbon was slightly acidic $(\mathrm{pH}$ 6.70). This kind of AC is preferable since the removal of polar organic compounds from water requires chemically bonded oxygen and hydrogen to solid carbon in the form of functional groups whose dissociation is $\mathrm{pH}$ dependent. The residue or ash content was 3.5\%. This low value suggests that bean husk is a good precursor of AC.

\section{CONCLUSION}

It can be said from this study that among the four activating agents used in the preparation of the activated carbon from bean husk, ortho-phosphoric acid $\left(\mathrm{H}_{3} \mathrm{PO}_{4}\right)$ was the best activating agent. The production conditions of $500^{\circ} \mathrm{C}$ carbonization temperature for 1 hour and activation temperature of $700^{\circ} \mathrm{C}$, for 30 minutes with impregnation ratio of $10: 5$ (highest iodine value) favoured the preparation.

The characterization of activated carbon from bean husk in terms of bulk/apparent density, ash content, moisture content, $\mathrm{pH}$ gave $0.41 \mathrm{~g} / \mathrm{l}, 3.5 \%, 8.5 \%, 6.7$ respectively. These values were found to fall within the specifications recommended by American Society for Testing and Materials (ASTM). The low value of density indicates high adsorptive capacity of the AC. The slightly acidic character $(\mathrm{pH}=6.7)$ gives the $\mathrm{AC}$ prominent sorption property in weak acids and bases aqueous solutions environments.

Bean husk is a good potential source of activated carbon on the one hand and the use of it to produce activated carbon helps in solving environmental pollution problems on the other hand.

\section{REFERENCES}

[1] Legrouri, K., Harti, M., Ouman, M., Khouya, E., Nahla, R., Hannache, H. and Zarouk, A. Characterization and Evaluation Performance of Activated Carbon Prepared from Coconut Shell argan, J. of Chem. \& Pharm. Res. 4(12)5081 5088, 2012.

[2] Rodriguez-Reinoso F., Molina-Sobia M. and Gonzalez G. C. Preparation of activated carbonsepiolite pellets. Carbon, 39, 771 - 785, 2001.
[3] Lafi W., Production of activated carbon from acrons and olive seed biomass. Biomass and Bioenergy, 20, 57-62, 2001.

[4] El-Hendawy A. A., Influence of $\mathrm{HNO}_{3}$ oxidation on the structured and adsorptive properties of corncob activated carbon. Carbon, 41, 713-722, 2003.

[5] Rengarag S., Seung-Hyeon Moon, Sivabalan S., Arabindoo B. and Murugesan V. Agricultural solid waste for the removal of organics: Adsorption of phenol from water and wastewater by palm seed coat activated carbon. Waste Management, 22, 543-548, 2002.

[6] Garcia F. S., Alonso A. M. and Tascon J. M. D. Porous texture of activated carbons prepared by phosphoric acid activation of apple pulp. Carbon, 39, 1103-1116, 2003.

[7] Rengarag S., Arabindoo B. and Murugesan V, Activated carbon from rubber seed and palm seed coat, preparation and characterization. J. Sci. and Ind. Res., 57, 129-132. 1996.

[8] Uraki, T., Ogawa, M., Gaman, S. and Tokura, S., Preparation of Activated Carbon from Peat. Bioresources 4(1) 205 - 213, 2009.

[9] Mui, E. L. K., Ko, D. C. K. and McKay, G. Production of active carbons from waste tyres-a review. Carbon 42 (14), 2789-2805, 2004.

[10] Khalili N. R., Campbell M., Sandi G. and Gola J., Production of micro and mesoporous activated carbon from paper mill sludge, I: Effect of zinc chloride activation. Carbon, 38, 1905-1915, 2000.

[11] Legrouri K., Ezzine M., Ichocho S., Hannache H., Denoyel R., Pailler R. and Naslain R, , Production of activated carbon from a new precursor: Molasses. J. Phys. IV France, 123, 101-104, 2005.

[12] Rozada, F., Calvo, L. F., Garcı'a, A. I., Martı́nVillacorta, J. and Otero, M.. Dye adsorption by sewage sludge-based activated carbons in batch and fixed-bed systems. Bioresour. Technol. 87(3), 221-230, 2003.

[13] Muthanna J. Ahmeda,b and Samar K. Dhedan ${ }^{b}$, Equilibrium isotherms and kinetics modeling of methylene blue adsorption on agricultural wastesbased activated carbons University of Baghdad, 2012,

[14] Hall K. R., Eagleton L. C., Acrivos A., and Vermeulen T. Ind. Eng. Chem. Fundam. 5 212223, 1966.

[15] Chengtang L., Hui X., Huaming L., Ling L., X. Li, and Zhixiang Y., Korean J. Chem. Eng. 28 (4) 11261132, 2011.

[16] ASTM Standard, Standard Test Method for Total Ash Content of Activated Carbon, Designation D2866-94, 2000. 